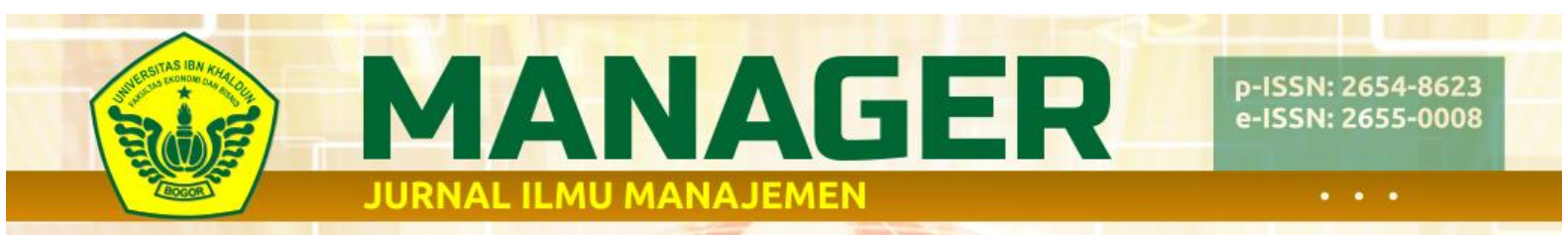

Vol. 3, No. 4, November 2020, Hal. 495-502

(c) (1) () http://ejournal.uikabogor.ac.id/index.php/Manager/index

\title{
PENGARUH JOB STRESS DAN JOB ROTATION TERHADAP KINERJA PEGAWAI
}

\author{
Fitri Nuraeni, Syahrum Agung, Rachmatullaily Tinakartika Rinda \\ Fakultas Ekonomi dan Bisnis Universitas Ibn Khaldun Bogor, Indonesia \\ Fitriinuraeni@yahoo.co.id, syahrumagung17@gmail.com, lailyrinda@yahoo.com
}

\begin{abstract}
Describe influence of Job Stress and Job Rotation on Performance of Bogor Regional Goverment Inspectorate. The sample were 60 respondents. Correlation analysis of Job Stress on Performance: $R=0,856$. Coefficient of determination $=0,733$, regression equation: $Y=$ 1,055 $+0,954 X_{1}$ and $T$ test hypothesis with $T$ arithmetic $=12,628>T$ table $=1.671$ there is influence significant between Job Stress and Performance. Correlation analysis of Job Rotation on Performance: $R=0,812$. Coefficient of determination $=0,660$, regression equation: $Y=4,261+0,977 X_{2}$ and $T$ test hypothesis with $T$ count $=10,613>T$ table $=$ 1.671 there is influence significant between Job Rotation to Performance. Correlation analysis of Job Stress and Job Rotation together on Performance: $R=0,868$. Regression function $Y=0,072+0,683 X_{1}+0,337 X_{2}$. The result coefficient of determination: 0,744. Because $F$ arithmetic $=86,701>F$ table $=3,16$ there is a significant influence between Job Stress and Job Rotation together towards Performance.
\end{abstract}

Keywords: Job Stress, Job Rotation, and Performance

\begin{abstract}
Abstrak
Menggambarkan pengaruh Job Stress dan Job Rotation terhadap Kinerja Pegawai pada Inspektorat Pemda Kabupaten Bogor. Dengan sampel 60 orang. Analisis korelasi pengaruh Job Stress terhadap Kinerja: $\mathrm{R}=0,856$. Koefisien determinasi $=0,733$, persamaan regresi: $\mathrm{Y}$ $=1,055+0,954 \mathrm{X}_{1}$ dan uji $\mathrm{T}$ hipotesis: $\mathrm{T}_{\text {hitung }}=12,628>\mathrm{T}_{\text {tabel }}=1.671$ berarti terdapat pengaruh signifikan antara Job Stress terhadap Kinerja. Analisis korelasi pengaruh Job Rotation terhadap Kinerja: $\mathrm{R}=0,812$. Koefisien determinasi $=0,660$, persamaan regresi: $\mathrm{Y}=$ $4,261+0,977 \mathrm{X}_{2}$ dan uji $\mathrm{T}$ hipotesis: $\mathrm{T}_{\text {hitung }}=10,613>\mathrm{T}_{\text {tabel }}=1.671$ berarti terdapat pengaruh signifikan antara Job Rotation terhadap Kinerja. Analisis pengaruh Job Stress dan Job Rotation secara bersama-sama terhadap Kinerja: $\mathrm{R}=0,868$. Fungsi regresi $\mathrm{Y}=0,072+$ $0,683 \mathrm{X}_{1}+0,337 \mathrm{X}_{2}$. Koefisien determinasi: 0,744. Karena $\mathrm{F}$ hitung $=86,701>\mathrm{F}$ tabel $=3,16$ berarti terdapat pengaruh signifikan antara Job Stress dan Job Rotation secara bersama-sama terhadap Kinerja.
\end{abstract}

Kata Kunci: Job Stress, Job Rotation, dan Kinerja 


\section{Pendahuluan}

Sumber daya manusia saat ini dianggap paling berharga dan memiliki peranan yang sangat penting dalam keberadaan serta kelangsungan hidup suatu organisasi. Sebuah organisasi tidak mungkin ada tanpa manusia, karena manusia merupakan elemen yang selalui dijumpai dalam setiap organisasi dan mempunyai dampak langsung pada kesejahteraan organisasi. Sumber daya manusia menjadi hal yang penting bagi kesuksesan organisasi. Sumber daya manusia yang bekerja secara profesional akan berdampak pada tinggi rendahnya kinerja organisasi tersebut.

Kunci keberhasilan dalam sebuah perusahaan maupun instansi terletak pada kinerja sumber daya manusia. Tinggi rendahnya kinerja organisasi akan sangat berpengaruh terhadap upaya organisasi dalam mencapai tujuannya. Dalam pencapaian tujuan suatu organisasi, masalah pengelolaan karyawan sudah menjadi hal yang umum. Sebagai instansi pemerintahan, Inspektorat Pemda Kabupaten Bogor belum menunjukkan profesionalisme kinerja yang baik. Dimana program-program tidak berjalan dengan baik, hal ini diakibatkan oleh terbatasnya sumber daya aparatur dan sumber daya anggaran dalam meningkatkan kinerja aparatur, manajemen pelayanan yang kurang memadai, minimnya kompetensi kerja aparatur dalam pelaksanaan kinerja pelayanan sarana dan prasarana sehingga menimbulkan kuatnya ego sektoral pada masing-masing unit kerja.

Dalam jurnal Manager (2019) oleh Rini Oktaviani, Syahrum Agung, Asti Marlina mengatakan kinerja pegawai dapat mengalami penurunan, hal ini dapat terjadi dikarenakan adanya motivasi kerja didalam diri mereka menurun dan adanya peluangpeluang untuk melakukan kecurangan. Kinerja instansi pemerintah semakin menjadi sorotan dan masyarakat mulai banyak menuntut nilai yang diperoleh atas pelayanan yang diberikan birokrasi pemerintah yang dipandang sebagai Pegawai Negeri Sipil. Apabila kenyataan tersebut diabaikan dan dibiarkan secara terus menerus, maka dapat mengganggu pencapaian tujuan organisasi yaitu Inspektorat Pemda Kabupaten Bogor. Dengan demikian kinerja merupakan bagian yang sangat penting dan menarik karena terbukti sangat penting manfaatnya. Kinerja sendiri mengacu pada kadar pencapaian tugas yang membentuk sebuah pekerjaan pegawai.

Penilaian kinerja suatu pegawai pada dasarnya merupakan faktor kunci guna mengembangkan suatu orgaisasi secara efektif dan efisien. Penilaian kinerja memungkinkan terjadinya komunikasi antara atasan dengan bawahan untuk meningkatkan kinerja serta mengevaluasi pengembangan apa saja yang dibutuhkan agar kinerja suatu pegawai semakin meningkat. Melalui perencanaan sumber daya manusia yang matang, maka kinerja dari tenaga kerja yang sudah ada dapat ditingkatkan. Hal ini dapat diwujudkan melalui adanya penyesuaian. Seperti pengarahan job stress dan job rotation yang baik dalam pekerjaan.

Dalam menjalankan pekerjaannya pegawai Inspektorat Pemda Kabupaten Bogor ini pun kerap kali menghadapi berbagai macam permasalahan, dikarenakan masih kurang optimalnya tingkat kinerja pegawai. Hal ini dapat dilihat dari banyaknya fenomena yang menunjukkan kurang optimalnya kinerja Inspektorat Pemda Kabupaten Bogor. Disamping itu setiap menjelang akhir bulan pegawai mendapat tekanan lebih tinggi karena harus membuat laporan bulanan. Sistem kerja yang terus bertarget membuat pegawai kewalahan dan tidak jarang merasa kelelahan dan cemas dalam bekerja sehingga karyawan merasa memiliki beban kerja yang berlebihan sebagai indikator job stress. Apabila hal ini dilakukan secara 
terus menerus akan berdampak negatif pada kondisi fisik dan psikis pegawai sehingga memungkinkan terjadinya pengaruh terhadap kinerja pegawai.

Menurut Moorhead dan Griffin (2013:175), job stress adalah suatu respon adaptif seseorang terhadap stimulus yang menempatkan tuntutan fisik atau psikologis secara berlebihan kepadanya. Kondisi stress yang positif dapat mendorong pegawai untuk bekerja pada tingkatan lebih tinggi, sedangkan stress yang negatif dapat menyebabkan menurunnya kinerja pegawai. Hal ini dapat dilihat dari peran dan jam kerja yang berlebihan yang dialami oleh pegawai. Jam kerja menurut Depnaker diatur dalam Undang-Undang yaitu, karyawan dianjurkan bekerja selama lima hari dalam satu minggu atau memiliki jam kerja total empat puluh jam seminggu. Bila dihitung perhari normalnya adalah 8 jam.

Setiap aspek pada pekerjaan dapat menjadi pembangkit stress. Tenaga kerja yang menentukan sejauh mana situasi yang dihadapi merupakan situasi stress. Berbagai tekanan yang dirasakan oleh pegawai dapat berasal dari faktor eksternal maupun faktor internal. Stress yang berlebihan akan mengakibatkan seseorang menjadi tidak jernih dalam berfikir dan bersikap serta sulit untuk mengambil keputusan yang tepat. Oleh karena itu, pengendalian job stress sangat diperlukan sehingga stress dapat berada dalam tingkatan yang tepat untuk meningkatkan kinerja pegawai. Disisi lain hal yang perlu diperhatikan bahwa job stress tidak selalu berdampak negatif terhadap kinerja pegawai.

Job rotation juga sering dilakukan atau bahkan dialami secara berkala oleh pegawai pada Inspektorat Pemda Kabupaten Bogor. Dengan job rotation, pegawai didorong untuk mengoptimalkan potensi dalam dirinya, menambah pengalaman dan pengetahuan, mengurangi kejenuhan terhadap suatu pekerjaan, dan memberikan kesempatan pegawai untuk mengembangkan karirnya. Bagi pegawai yang menyukai tantangan dan ingin mengembangkan karirnya dengan cepat, ini merupakan suatu hal yang positif. Namun ada saja penghambat yang terjadi yaitu tidak semua pegawai menginginkan rotasi kerja. Bahkan bagi pegawai yang sudah merasa nyaman pada penempatan kerjanya mereka cenderung protes. Alasan lain dari enggannya pegawai melakukan rotasi wilayah kerja yaitu jarak lokasi pekerjaan yang dirasa lebih jauh dari tempat tinggal mereka. Dalam menghadapi job rotation karyawan juga tentu memerlukan kemampuan beradaptasi dengan lingkungan organisasi dan lingkungan kerja yang baru.

Menurut Nurlatifah (2009:3), job rotation selain berfungsi bagi pengembangan sumber daya manusia, diyakini dapat memberikan banyak manfaat lain bagi organisasi. Job rotation dapat mencegah timbulnya kebosanan, dapat mengurangi labour turnover (absennya pekerja) pegawai sehingga efektif dalam bekerja. Dengan adanya job rotation sebuah posisi atau jabatan tidak akan ditempati oleh seseorang dalam jangka waktu yang lama. Dengan mengetahui hubungan job stress yang dialami pegawai terhadap kinerjanya dan seberapa besar job stress yang dianggap efektif dalam mendorong kinerja pegawai, diharapkan dapat mengoptimalisasi kemampuan terbaik pegawai dalam bekerja. Demikian pula dengan job rotation yang efektif dan tepat sasaran dapat menjadi salah satu faktor penting dalam memaksimalkan potensi kinerja pegawai. Kolaborasi hubungan antara job stress dan job rotation terhadap kinerja karyawan diharapkan mampu memberikan hasil kesimpulan yang dapat memberikan informasi yang berguna sehingga dapat menghasilkan kinerja yang baik dan sesuai dengan pencapaian tujuan.

\section{Tujuan Penelitian}

Tujuan penelitian merupakan jawaban atau sasaran yang ingin dicapai penulis dalam sebuah penelitian. Maka 
tujuan penelitian ini adalah untuk menjelaskan pengaruh job stress terhadap kinerja pegawai pada Inspektorat Pemda Kabupaten Bogor, adalah untuk menjelaskan pengaruh job rotation terhadap kinerja pegawai pada Inspektorat

\section{Metode Penelitian}

Ruang lingkup penelitian ini adalah pengaruh Job Stress dan Job Rotation terhadap Kinerja Pegawai pada Inspektorat Pemda Kabupaten Bogor. Lokasi penelitian beralamatkan di Komplek Pemerintah Daerah Kabupaten Bogor, J1. Indah No.1 Cibinong Kabupaten Bogor, 16914. Variabel yang dikaji dalam penelitian ini adalah : Job Stress $\left(\mathrm{X}_{1}\right)$ dan Job Rotation $\left(\mathrm{X}_{2}\right)$ sebagai variabel independent (bebas), dan Kinerja (Y) sebagai variabel dependent (terikat). Dari variabel tersebut ditetapkan indikatornya kemudian membuat kuesioner sesuai tujuan dengan menggunakan skala Likert yang umumnya menggunakan 5 (lima) angka penilaian dan mempunyai kriteria jawaban sebagai berikut : Sangat Setuju (SS) Skor 5, Setuju (S) Skor 4, Netral (N) Skor 3, Tidak Setuju (TS) Skor 4, dan Sangat Tidak Setuju (STS) Skor 1. Validitas dapat didefinisikan sebagai ukuran untuk menilai apakah alat ukur yang digunakan benar-benar mampu memberikan nilai perubahan yang ingin diukur. Data yang valid adalah data yang tidak berbeda antara data yang dilaporkan

\section{Hasil dan Pembahasan}

\section{Uji Validitas dan Reliabilitas}

Untuk hasil validitas dan reabilitas terdapat keseluruhan item variabel

diperoleh $\mathrm{r}$ tabel $=0,250$ sehingga dapat dikatakan bahwa keseluruhan item penelitian adalah valid untuk digunakan sebagai instrumen dalam penelitian atau pertanyaan-pertanyaan yang diajukan dapat digunakan untuk mengukur variabel yang
Pemda Kabupaten Bogor, untuk menjelaskan pengaruh kinerja pegawai pada Inspektorat Pemda Kabupaten Bogor, untuk menjelaskan pengaruh job stress dan job rotation terhadap kinerja pegawai pada Inspektorat Pemda KabupatenBogor.

oleh peneliti dengan data yang sesungguhnya terjadi ada objek penelitian. Uji Validitas dapat menggunakan teknik korelasi produk moment dengan melihat korelasi antar item pertanyaan jika Rhitung $>$ Rtabel pada nilai signifikasi yang ditetapkan maka dinyatakan valid sementara jika Rhitung < Rtabel pada signifikasi yang ditetapkan maka dinyatakan tidak valid. Instrumen yang reliabel adalah instrumen yang bila digunakan beberapa kali untuk mengukur objek yang sama, akan menghasilkan data yang sama. Setelah instrumen di uji validitasnya maka langkah selanjutnya yaitu menguji reliabilitas. Uji reliabilitas dilakukan untuk mengetahui apakah suatu instrumen penelitian cukup dapat dipercaya untuk dapat digunakan sebagai alat pengumpul data, sehingga akan menghasilkan data yang dapat dipercaya juga. Dalam penelitian ini, uji reliabilitas dilakukan dengan menggunakan teknik Formula Alpha Cronbach dan dengan menggunakan program komputer. Uji reliabilitas dapat dilakukan secara bersamasama terhadap seluruh butir pertanyaan dan Jika nilai Alpha > 0,60 makareliabel.

penelitian yaitu Job Stress, Job Rotation dan Kinerja yang mempunyai $r$ hitung $>r$ tabel yaitu pada signifikansi $95 \%(\alpha=0,05)$, dan $\mathrm{n} \quad 60 \quad$ dapat

diteliti. Dengan melihat Cronbach's Alpha maka dapat disimpulkan bahwa pertanyaan dalam kuesioner Job Stress, Job Rotation dan Kinerja adalah reliabel dan dapat diterima. 


\section{Analisis Pengaruh Antara Job Stress $\left(\mathrm{X}_{1}\right)$ dengan Kinerja (Y)}

\section{Analisis Korelasi}

Pada analisis korelasi $\mathrm{X}_{1}$ terhadap $\mathrm{Y}$ menunjukan nilai $\mathrm{R}=0,856$ terletak pada interval 0,80-1,000 (Sangat Kuat), hal ini menunjukan bahwa pengaruh antara variabel $\mathrm{X}_{1}$ (persepsi terhadap Job Stress) dan Y (persepsi terhadap Kinerja) adalah Sangat Kuat dan Positif. Berarti apabila $\mathrm{X}_{1}$ naik maka Y juga naik.

\section{Analisis Regresi}

Persamaan regresi yang terbentuk adalah $\mathrm{Y}=1,055+0,954 \mathrm{X}_{1}$. Interprestasi atau konstanta sebesar 1,055, berarti apabila variabel bebas $\mathrm{X}_{1}$ (Job Stress) sama dengan nol, maka besarnya variabel Y (Kinerja) adalah 1,055. Dengan kata lain, jika variabel bebas $\mathrm{X}_{1}$ (Job Stress) nilainya dianggap nol berarti besarnya variabel kinerjanya adalah 1,055 . Variabel $\mathrm{X}_{1}$ ( $\mathrm{Job}$

\section{Analisis Pengaruh Antara Job Rotation $\left(\mathrm{X}_{2}\right)$ dan Kinerja $(\mathrm{Y})$}

\section{Analisis Korelasi}

Pada analisis korelasi $\mathrm{X}_{2}$ terhadap $\mathrm{Y}$ menunjukan nilai $\mathrm{R}=0,812$ terletak pada interval $(0,80-1,000)$ hal ini menunjukkan bahwa pengaruh antara variabel $\mathrm{X}_{2}$ (persepsi terhadap Job Rotation) dan Y (persepsi terhadap Produktivitas) adalah Sangat Kuat dan Positif. Berarti apabila $\mathrm{X}_{2}$ naik maka Y juga naik.

\section{Analisis Regresi}

Persamaan regresi yang terbentuk adalah $\mathrm{Y}=4,261+0,977 \mathrm{X}_{2}$, berarti apabila variabel bebas $\mathrm{X}_{2}$ (Job Rotation) sama dengan nol, maka besarnya variabel Y (Kinerja) adalah 4,261. Dengan kata lain, jika variabel bebas $\mathrm{X}_{2}$ (Job Rotation) nilainya dianggap nol berarti besarnya
Stress) 0,954 ini berarti pengaruh $\mathrm{X}_{1}$ (Job Stress) terhadap Y (Kinerja) adalah positif atau setiap kenaikan nilai skor Variabel $\mathrm{X}_{1}$ (Job Stress) sebesar 1, maka akan meningkatkan nilai skor variabel $\mathrm{Y}$ (Kinerja) sebesar 0,954.

\section{Analisis Koefisien Determinasi}

Hasil koefisien determinasi sebesar 0,733 atau $(73,3 \%)$ memberikan arti bahwa besarnya pengaruh Variabel $\mathrm{X}_{1}$ (Job Stress) terhadap Kinerja sebesar 73,3\%, sedangkan sisanya $26,7 \%$ dipengaruhi oleh faktor-faktor lain yang tidak dimasukkan dalam penelitian ini.

\section{Uji Hipotesis Parsial (Uji T)}

Menunjukkan $\mathrm{T}_{\text {hitung }}=12,628>\mathrm{T}_{\text {tabel }}$ $=1.671$, maka $\mathrm{H}_{\mathrm{o}}$ ditolak $\left(\mathrm{H}_{\mathrm{a}}\right.$ diterima $)$ berarti bahwa terdapat pengaruh yang signifikan antara Job Stress terhadap Kinerja.

variabel Kinerja adalah 4,261. Variabel $\mathrm{X}_{2}$ (Job Rotation) 0,977 ini berarti pengaruh $\mathrm{X}_{2}$ (Job Rotation) terhadap Y (Kinerja) adalah positif atau setiap kenaikan nilai skor Variabel $\mathrm{X}_{2}$ (Job Rotation) sebesar 1, maka akan meningkatkan nilai skor variabel Y (Kinerja) sebesar 0,977.

\section{Analisis Koefisien Determinasi}

Hasil koefisien determinasi sebesar 0,660 atau (66,0\%) memberikan arti bahwa besarnya pengaruh Variabel $\mathrm{X}_{2} \quad(\mathrm{Job}$ Rotation) terhadap Kinerja sebesar $66,0 \%$, sedangkan sisanya $34,0 \%$ dipengaruhi oleh faktor-faktor lain yang tidak dimasukkan dalam penelitian ini. 


\section{Uji Hipotesis Parsial (Uji T)}

Menunjukkan $\mathrm{T}_{\text {hitung }}=10,613>\mathrm{T}$ tabel $=1.671$, maka $H_{\mathrm{o}}$ ditolak $\left(\mathrm{H}_{\mathrm{a}}\right.$ diterima $)$

\section{Analisis Hubungan Antara Job Stress $\left(\mathrm{X}_{1}\right)$, Job Rotation $\left(\mathrm{X}_{2}\right)$ dan Kinerja}

\section{Analisis Korelasi}

Pada analisis korelasi $\mathrm{X}_{1}, \mathrm{X}_{2}$ terhadap $\mathrm{Y}$ menunjukan nilai $\mathrm{R}=0,868$ terletak pada interval $(0,80-1,000)$ hal ini menunjukkan bahwa pengaruh antara variabel $X_{1}$ (persepsi terhadap Job Stress), $\mathrm{X}_{2}$ (persepsi terhadap Job Rotation) secara bersamasama terhadap $\mathrm{Y}$ (persepsi terhadap Kinerja) adalah Sangat Kuat dan Positif. Berarti secara bersama-sama kenaikan $X_{1}$ dan $\mathrm{X}_{2}$ akan menyebabkan kenaikan $\mathrm{Y}$.

\section{Analisis Regresi}

Persamaan regresi yang terbentuk adalah $\mathrm{Y}=0,072+0,683 \mathrm{X}_{1}+0,337 \mathrm{X}_{2}$, berarti apabila variabel bebas $\left(\mathrm{X}_{1}\right) \mathrm{Job}$ Stress dan $\mathrm{X}_{2}$ (Job Rotation) sama dengan nol, maka besarnya variabel Y (Kinerja) adalah 0,072. Dengan kata lain, jika variabel bebas $\left(\mathrm{X}_{1}\right)$ Job Stress dan $\mathrm{X}_{2}(J o b$ Rotation) nilainya dianggap nol berarti besarnya adalah 0,072. Variabel $\left(\mathrm{X}_{1}\right) J o b$ Stress sebesar 0,683 ini berarti pengaruh $\left(\mathrm{X}_{1}\right)$ Job Stress terhadap (Y) Kinerja adalah positif atau setiap kenaikan nilai skor Variabel $\left(\mathrm{X}_{1}\right)$ Job Stress sebesar 1, maka akan meningkatkan nilai skor variabel $\mathrm{Y}$ (Kinerja) sebesar 0,683. Variabel $\mathrm{X}_{2}$ ( $\mathrm{Job}$ Rotation) sebesar 0,337 ini berarti

\section{Kesimpulan dan Saran}

\section{Kesimpulan}

Berdasarkan hasil dan pembahasan mengenai Pengaruh Job Stress dan Job Rotation Terhadap Kinerja Pegawai Pada Inspektorat Pemda Kabupaten Bogor, maka kesimpulan yang dapat ditarik dari penelitian ini adalah sebagai berikut : berarti bahwa terdapat pengaruh yang signifikan antara Job Rotation terhadap Kinerja

pengaruh $\mathrm{X}_{2}$ (Job Rotation) terhadap $\mathrm{Y}$ (Kinerja) adalah positif atau setiap kenaikan nilai skor Variabel $\mathrm{X}_{2}$ (Job Rotation) sebesar 1, maka akan meningkatkan nilai skor variabel Y (Kinerja) sebesar 0,337.

\section{Analisis Koefisien Determinasi}

Hasil koefisien determinasi sebesar 0,753 atau $(75,3 \%)$ dan koefisien determinasi yang disesuaikan adalah sebesar 0,744 atau (74,4\%). Karena persamaan regresi menggunakan banyak variabel independen, maka koefisien yang digunakan untuk menjelaskan persamaan ini adalah koefisien determinasi yang disesuaikan sebesar 0,744 atau $(74,4 \%)$ memberikan arti bahwa besarnya Variabel $\mathrm{X}_{1}$ Job Stress dan $\mathrm{X}_{2}$ (Job Rotation) secara bersama-sama terhadap Kinerja sebesar $74,4 \%$, sedangkan sisanya $25,6 \%$ dipengaruhi oleh faktor-faktor lain yang tidak dimasukkan dalam penelitian ini.

\section{Uji Hipotesis Simultan (Uji F)}

Menunjukkan $\mathrm{F}_{\text {hitung }}=86,701>\mathrm{F}$ tabel $=3,16$, maka $\mathrm{H}_{\mathrm{o}}$ ditolak $\left(\mathrm{H}_{\mathrm{a}}\right.$ diterima $)$ berarti bahwa terdapat pengaruh yang signifikan antara Job Stress dan Job Rotation secara bersama-sama terhadap Kinerja.

1. Hubungan Job Stress terhadap Kinerja Pegawai Pada Inspektorat Pemda Kabupaten Bogor memiliki nilai $\mathrm{R}=$ 0,856 terletak pada interval $(0,80-$ 1,000) hal ini menunjukkan bahwa terdapat pengaruh yang Sangat Kuat dan Positif. Hasil koefisien determinasi sebesar 0,733 atau $73,3 \%$ memberikan 
arti bahwa besarnya pengaruh Variabel $\mathrm{X}_{1} \quad($ Job Stress $)$ terhadap Kinerja sebesar 73,3\%. Hasil analisis regresi $\mathrm{Y}$ $=1,055+0,954 \mathrm{X}_{1}$ dan Uji $\mathrm{T}$ hipotesis parsial dengan $\mathrm{T}_{\text {hitung }}=12,628>\mathrm{T}$ tabel $=1.671$, maka Ho ditolak $(\mathrm{Ha}$ diterima) berarti bahwa terdapat pengaruh yang signifikan antara $J o b$ Stress terhadap Kinerja.

2. Hubungan Job Rotation terhadap Kinerja Pegawai Pada Inspektorat Pemda Kabupaten Bogor memiliki nilai $\mathrm{R}=0,812$ terletak pada interval $(0,80-1,000)$ hal ini menunjukkan bahwa terdapat pengaruh yang Sangat Kuat dan Positif. Hasil koefisien determinasi sebesar 0,660 atau 66,0\% memberikan arti bahwa besarnya pengaruh Variabel $\mathrm{X}_{2}$ (Job Rotation) terhadap Kinerja sebesar $66,0 \%$. Hasil analisis regresi $\mathrm{Y}=4,261+0,977 \mathrm{X}_{2}$ dan Uji $\mathrm{T}$ hipotesis parsial dengan $\mathrm{T}$ hitung $=10,613>\mathrm{T}$ tabel $=1.671$, maka Ho ditolak (Ha diterima) berarti bahwa terdapat pengaruh yang signifikan antara Job Rotation terhadap Kinerja.

3. Kinerja pada Inspektorat Pemda Kabupaten Bogor menunjukkan bahwa persepsi responden terhadap kinerja yaitu sebesar 3,54 (pada skala 1-5) interval $(3,41-4,20)$ dengan kategori Baik, dengan indikator yang paling dominan yaitu ketepatan waktu dimana menyelesaikan pekerjaan sesuai target dan tidak menunda-nunda pekerjaan yang ada. Perincian penilaian responden terdiri dari 10 responden memberikan persepsi Sangat Setuju (SS), 20 responden memberikan persepsi Setuju (S) dan 30 responden memberikan persepsi Netral $(\mathrm{N})$.

4. Hubungan Job Stress dan Job Rotation secara bersama-sama terhadap Kinerja Pegawai Pada Inspektorat Pemda Kabupaten Bogor memiliki nilai $\mathrm{R}=$ 0,868 terletak pada interval $(0,80-$ 1,000) hal ini menunjukkan bahwa terdapat pengaruh yang Sangat Kuat dan Positif. Hasil koefisien determinasi yang disesuaikan sebesar 0,744 atau
$74,4 \%$ memberikan arti bahwa besarnya pengaruh Variabel X_1 ( Job Stress) dan X_2 (Job Rotation) secara bersama-sama terhadap Kinerja sebesar 74,4\%. Hasil analisis regresi $\mathrm{Y}$ $=0,072+0,683$ X_1 + 0,337 X_2 dan Uji Hipotesis dengan menggunakan $\mathrm{F}$ hitung $=86,701>\mathrm{F}_{\text {tabel }}=3,16$ maka Ho ditolak (Ha diterima) berarti bahwa terdapat pengaruh yang signifikan antara Job Stress dan Job Rotation secara bersama-sama terhadap Kinerja.

\section{Saran}

Berdasarkan hasil penelitian, maka penulis memberikan beberapa saran antara lain :

1. Pada variabel Job Stress terhadap kinerja, Inspektorat Pemda Kabupaten Bogor perlu melakukan pelatihan kerja maupun manajemen stress sehingga pegawai dapat melakukan pekerjaan secara efisien selain itu mampu meminimalisir masalah dalam pekerjaan serta mengetahui bagaimana mengatasi dan mengelola berbagai masalah dalam pekerjaan. Instansi pun perlu melakukan apresiasi lebih terhadap prestasi dan pencapaian kinerja pegawai melalui peningkatan kompensasi seperti insentif, bonus, tunjangan dan cuti. Instansi dan pimpinan dapat dilakukan dengan memberikan pujian, peluang promosi, dan lain-lain. Dengan begitu pegawai merasa lebih termotivasi dan tidak merasa tertekan dalam bekerja.

2. Pada variabel Job Rotation terhadap kinerja, Inspektorat Pemda Kabupaten Bogor dalam melaksanakan job rotation sebaiknya pimpinan juga mempertimbangkan kebijakan yang dijalankan dengan idealnya melakukan job rotation terhadap pegawai yang telah cukup lama berada pada posisi unit kerja yang sama, sehingga ketika kebijakan ini dilaksanakan dapat meningkatkan pengetahuan, keahlian pegawai dan menghindarkan adanya 
kebosanan dalam menghadapi tugas, karena setiap pegawai memiliki kesempatan yang sama untuk peningkatan dan pengembangan karir.

3. Pada variabel kinerja menunjukkan bahwa kinerja pada Inspektorat Pemda Kabupaten Bogor termasuk dalam kategori baik, namun sebaiknya instansi tetap mendorong semangat kerja pegawai untuk menata ulang proporsi kualitas dan kuantitas pegawai agar menjadi lebih baik lagi serta memotivasi pegawai untuk berprestasi dalam bekerja. Kemudian

\section{Daftar Pustaka}

Affandi, P. (2016). Konsep dan Indikator Manajemen Sumber Daya Manusia. Yogyakarta: Zanafa Publishing.

Hasibuan, M. (2009). Manajemen Sumber Daya Manusia. Jakarta : PT. Bumi Aksara

Mangkunegara, Anwar Prabu. (2001). Manajemen Sumber Daya Perusahaan. Bandung: PT. Remaja Rosdakarya.

Moorhead \& Griffin (2013). Perilaku Organisasi Manajemen Sumber Daya Manusia dan Organisasi. Jakarta: Salemba Empat.

Robbins, S. P. (2009). Perilaku Organisasi. Jakarta : Salemba Empat.

Sondang P. Siagian. (2014). Manajemen Sumber Daya Manusia. Jakarta : Bumi Aksara.

\section{Jurnal Diunduh Dari Internet}

Nurlatifah. (2009). Pengaruh Rotasi Kerja Terhadap Kinerja Pustakawan di Perpustakaan UGM Yogyakarta melakukan pendekatan individual antara pimpinan dengan pegawai melalui pola komunikasi yang baik dan terarah sehingga kinerja pegawai menjadi semakin meningkat.

4. Dalam penelitian selanjutnya disarankan menggunakan variabel lain yang belum digunakan dalam penelitian ini sehingga dapat diperoleh informasi faktor-faktor lainnya yang juga dapat berpengaruh atau signifikan terhadap kondisi kerja Inspektorat Pemda Kabupaten Bogor.

[Internet]. [Diunduh 2018, 09, 25, pukul 19.05] : tersedia pada : http://digiblin.uinsuka.ac.id/id/eprint/3658

Oktaviani, R., Agung, S., \& Marlina Asti. (2019). Kepemimpinan dan Human Capital Terhadap Kinerja Karyawan. [Internet]. [Diunduh 2019, 08, 10, pukul 15.00] : tersedia pada http://ejournal.uikabogor.ac.id/index.php/Manager 